Standfast, A. F. B. (1951). J. gen. Microbiol. 5, 250-267.

\title{
The Virulence of Haemophilus pertussis for Mice by the Intranasal Route
}

\author{
By A. F. B. STANDFAST \\ The Lister Institute of Preventive Medicine, Elstree, Hertfordshire
}

With a note by J. O. IRwIN on the relation between LD 50 and average time to death in 25 strains of $H$. pertussis

SUMMARY : Freshly isolated strains of Haemophilus pertussis vary considerably in their virulence for mice when tested by the intranasal route; this variation is continuous and must be regarded as a quantitative not a qualitative character. In order to titrate virulence it is necessary to achieve and maintain a standard technique with cultures and to use 'standard' mice kept under standardized conditions. It was not possible to show a correlation between virulence (as measured by the LD 50) and either the viable count or the presence of toxin or haemagglutinin in the suspensions used in the virulence test. Nor was it possible to show any correlation between virulence and the 'age' of the culture, either in number of subcultures, time elapsing between swabbing and testing, type of swab or duration of illness (up to three weeks) when the swab was taken. Some strains kill mice more quickly than others; this ability is attributed to a 'quick-killing factor'.

The experiments reported here were designed to titrate the virulence of Haemophilus pertussis by the intranasal technique of Burnet \& Timmins (1937) in order to show whether freshly isolated strains of this organism from different cases or from different epidemics varied in virulence as strains of other organisms appear to. A survey of the literature shows that considerable differences in the virulence of different strains have been reported, though details of the strains are seldom given. It was also hoped to correlate the variations in virulence which were found with certain other factors which it was felt might be involved. First, certain details of method are stressed, since it soon became obvious that in work of this sort it was more important to develop a standarized technique, which was thereafter rigidly adhered to, than to change the technique constantly by the introduction of improvements.

\section{MATERIAL AND METHODS}

Collection of strains. Strains of $\boldsymbol{H}$. pertussis examined were freshly isolated from patients with whooping-cough in Colindale, Leeds, Manchester and Oxford. The first subculture from the original cough- or swab-plate was sent to this laboratory. All strains reported in this paper were in Phase I of Leslie \& Gardner (1931) in that they agglutinated to titre with Phase I serum and would only grow on Bordet-Gengou medium.

No attempt was made to isolate cultures from single colonies; in most cases a heavy inoculum from confluent growth was used. When separate colonies only were available at least twelve colonies were picked off with a loop for a single subculture. 


\section{Method of test}

Preparation of bacterial suspensions. Each strain was grown on BordetGengou medium for $20 \mathrm{hr}$., the growth scraped off into $1 \%$ Bacto-casamino acids (Baird \& Tatlock, London) and standardized by opacity against Brown's Opacity Tubes (Burroughs Wellcome and Co. Ltd., London) assuming that $\boldsymbol{H}$. pertussis was equivalent to $\boldsymbol{H}$. pfeiffer. Four dilutions were used containing 2500, 250, 25 and 2.5 million organisms $/ \mathrm{ml}$., as the end-point usually lay within this range. Not more than $2 \mathrm{hr}$. was allowed to elapse between the dilution of the culture and the last instillation of the mice.

The importance of the age of the culture has been stressed by Gray (1946) and this has been confirmed (see Table 1).

Table 1. Virulence of an Haemophilus pertussis strain (C4039, second subculture) after different periods of incubation

$\begin{array}{ccc}\begin{array}{c}\text { Period of } \\ \text { incubation (hr.) }\end{array} & \text { LD } 50 \text { (millions) } & \begin{array}{c}\text { Haemagglutinin } \\ \text { titre }\end{array} \\ 20 & 0 \cdot 58 & 24 \\ 42 & 6 \cdot 5 & 192 \\ 70 & 31 \cdot 0 & 394\end{array}$

Mice. All mice used came from the same closely bred strain. For each test 40 mice, all of one sex and weighing 14-18 g., were distributed at random into four boxes, each dose being tested in 10 mice. They were fed on Rowett Research Institute pellets (North-Eastern Agricultural Co-operative Society, Aberdeen) for the whole of the experiment and were given water ad lib. The importance of using the same strain of mice is shown in Table 2, which compares the virulence of the same subculture of an $H$. pertussis strain tested in three batches of mice from different sources. Whereas mice from sources S1 and $\mathbf{C}$ are about the same, mice from source $\mathbf{S} 2$ differ very considerably in their susceptibility to pertussis infection.

Table 2. Comparison of virulence of Haemophilus pertussis, strain no. 323, in mice from three different sources

\begin{tabular}{crr} 
& \multicolumn{2}{c}{ LD 50 (on 21st day) } \\
\cline { 2 - 3 } Strain of mice & Test 1 & Test 2 \\
S 1 & $40 \cdot 0$ & $80 \cdot 0$ \\
C1 & $33 \cdot 0$ & $60 \cdot 0$ \\
S2 & $170 \cdot 0$ & $200 \cdot 0$
\end{tabular}

Culotta, Martin \& Liebow (1938) drew attention to the importance of weight or size of mice in experimental infection with $\boldsymbol{H}$. pertussis; with a standard dose and using the same strain they found $93 \%$ mortality in young mice weighing 10-12 g. and only 66\% mortality in adult mice weighing 20-25 g. This has been confirmed, and Table 3 shows the importance of the weight of the mice used in work of this kind. 
Table 3. Comparison of the LD50 of the same strains tested simultaneously in mice of different weights

\begin{tabular}{|c|c|c|c|}
\hline Strain of $\boldsymbol{H}$. pertussis & Group & $\begin{array}{c}\text { Average weight } \\
\text { of mice at start } \\
\text { of experiment } \\
\text { (g.) }\end{array}$ & $\underset{\text { (millions) }}{\text { LD 50 }}$ \\
\hline Cro467 & $\begin{array}{l}\text { A } \\
\text { B } \\
\text { C }\end{array}$ & $\begin{array}{l}14 \cdot 2 \\
21 \cdot 3 \\
27 \cdot 0\end{array}$ & $\begin{array}{c}0.67 \\
2 \cdot 1 \\
56 \cdot 0\end{array}$ \\
\hline C247649 & $\begin{array}{l}\mathbf{A} \\
\mathbf{B}\end{array}$ & $\begin{array}{l}15 \cdot 5 \\
24 \cdot 0\end{array}$ & $\begin{array}{l}0.66 \\
8.7\end{array}$ \\
\hline
\end{tabular}

Procedure. The mice were anaesthetized with an ether-chloroform mixture and a dose of 2 drops of each dilution from a pipette, calibrated to deliver $50 \mathrm{drops} / \mathrm{ml}$., was given to each mouse (i.e. doses of 100, 10, 1 and $0 \cdot 1$ million organisms). Only those mice which absorbed the dose quickly and completely were included in the test; any mouse which sneezed, blew or swallowed the dose or part of the dose was excluded. Mice which swallow some of the dose are sometimes difficult to detect and may account for some of the unexpected survivors. The mice were watched in the early experiments for $\mathbf{5 6}$ days and in the later experiments for 28 days. Mice dying within $24 \mathrm{hr}$. were considered 'accidents' and excluded.

Table 4 shows four strains of high, medium and low potency.

Statistical treatment of results. The virulence of different strains was measured by the LD 50, calculated by the method of Reed \& Muench (1938) from the figures obtained from the four dose levels actually used.

In the first series of twenty-five strains the LD50 was determined for each week up to 8 weeks (Table 5). Although the LD 50 of some strains continued to fall with the passage of time, there was little change in the order of virulence of the strains. It was decided that 4 weeks was a reasonable period to keep the mice and that the virulence of a strain should be measured by the LD50 calculated by the Reed \& Muench method on the 28th day. For convenience, strains were arranged in five arbitrarily chosen groups, as follows: group A,

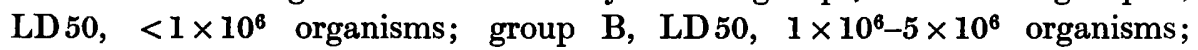
group C, LD 50, $5 \times 10^{6}-25 \times 10^{6}$ organisms; group D, LD 50, $25 \times 10^{6}-$ $125 \times 10^{6}$ organisms; group E, LD 50, >125 $\times 10^{6}$ organisms.

Reproducibility of results. It is difficult in this type of testing to reproduce the exact condition of a test. On several occasions tests were set up in parallel to show whether comparative results could be obtained (Table 6). These tests probably show a degree of accuracy and reproducibility not always achieved.

\section{RESULTS}

When the first series of strains of $\boldsymbol{H}$. pertussis was tested, mice were not always immediately available, and certain of the cultures of $\boldsymbol{H}$. pertussis which were contaminated, had to be plated once or twice to purify them. The great variation in virulence shown by these strains (Table 5) suggested that they might be 
undergoing some form of degeneration, although they remained in Phase I by agglutination. A second series was therefore tested in which only those challenge suspensions which could be prepared from the 2nd or 3rd subculture from the cough-plate were used. The same variations occurred in this series. Details of the day on which the swabs were taken, etc., were obtained for each strain,

Table 4. Details of intranasal virulence test on Haemophilus pertussis strains of high, medium and low virulence

\begin{tabular}{|c|c|c|c|c|c|c|c|c|c|c|c|}
\hline \multicolumn{2}{|c|}{$\begin{array}{cc}\text { Dose } \\
\text { Strain of } & (\text { no. of } \\
\left.H . \text { pertussis cells } \times 10^{6}\right)\end{array}$} & \multicolumn{10}{|c|}{ Day of death of ten mice } \\
\hline \multirow[t]{4}{*}{ G928 } & 100 & 2 & 2 & 2 & 2 & 2 & 2 & $\mathbf{3}$ & $\mathbf{3}$ & 6 & 6 \\
\hline & 10 & 3 & 3 & 3 & 8 & 9 & 9 & 10 & 11 & 14 & 17 \\
\hline & 1 & 10 & 19 & 37 & 43 & $\mathbf{S}$ & $\mathbf{S}$ & $\mathbf{S}$ & $\mathbf{S}$ & $\mathbf{S}$ & $\mathbf{S}$ \\
\hline & $0 \cdot 1$ & 23 & 26 & $\mathbf{S}$ & $\mathbf{S}$ & $\mathbf{S}$ & $\mathbf{S}$ & $\mathbf{S}$ & $\mathbf{S}$ & $\mathbf{S}$ & $\mathbf{S}$ \\
\hline \multirow{4}{*}{ G 1041 } & 100 & 6 & 6 & 6 & 6 & 6 & 7 & $\mathbf{9}$ & 12 & 13 & $a$ \\
\hline & 10 & 12 & 14 & 18 & 20 & 23 & 24 & 28 & 32 & $\mathbf{S}$ & $a$ \\
\hline & 1 & 31 & 33 & 41 & 43 & 46 & 53 & $\mathbf{S}$ & $\mathbf{S}$ & $\mathbf{S}$ & $\mathbf{S}$ \\
\hline & $0 \cdot 1$ & 21 & 29 & 50 & 50 & $\mathbf{S}$ & $\mathbf{S}$ & $\mathbf{S}$ & $\mathbf{S}$ & $\mathbf{S}$ & $\mathbf{S}$ \\
\hline \multirow[t]{4}{*}{ G942 } & 100 & 2 & 9 & 9 & 10 & 13 & 14 & 15 & 15 & 18 & $\mathbf{S}$ \\
\hline & 10 & 10 & 10 & 21 & $\mathbf{S}$ & $\mathbf{S}$ & $\mathbf{S}$ & $\mathbf{S}$ & $\mathbf{S}$ & $\mathrm{S}$ & $\mathbf{S}$ \\
\hline & 1 & 8 & 32 & $\mathbf{S}$ & $\mathbf{S}$ & $\mathbf{S}$ & $\mathbf{S}$ & $\mathbf{S}$ & $\mathbf{S}$ & $\mathbf{S}$ & $\mathbf{S}$ \\
\hline & $0 \cdot 1$ & 26 & $\mathbf{S}$ & $\mathbf{S}$ & $\mathbf{S}$ & $\mathbf{S}$ & $\mathbf{S}$ & $\mathbf{S}$ & $\mathbf{S}$ & $\mathbf{S}$ & S \\
\hline \multirow[t]{4}{*}{ M5 } & 100 & 11 & 27 & 27 & $\mathbf{S}$ & $\mathbf{S}$ & $\mathbf{S}$ & $\mathbf{S}$ & $\mathbf{S}$ & $\mathbf{S}$ & $\mathbf{S}$ \\
\hline & 10 & $\mathbf{S}$ & $\mathbf{S}$ & $\mathbf{S}$ & $\mathbf{S}$ & $\mathbf{S}$ & $\mathbf{S}$ & $\mathbf{S}$ & $\mathbf{S}$ & $\mathbf{S}$ & $\mathbf{S}$ \\
\hline & 1 & 15 & $\mathbf{S}$ & $\mathbf{S}$ & $\mathbf{S}$ & $\mathbf{S}$ & $\mathbf{S}$ & $\mathbf{S}$ & $\mathbf{S}$ & $\mathbf{S}$ & S \\
\hline & $0 \cdot 1$ & 54 & 54 & $\mathbf{S}$ & $\mathbf{S}$ & $\mathbf{S}$ & $\mathbf{S}$ & $\mathbf{S}$ & $\mathbf{S}$ & $\mathbf{S}$ & $S$ \\
\hline
\end{tabular}

$\mathrm{S}=$ survivor $; a=$ mouse lost by accident.

\begin{tabular}{|c|c|c|c|c|c|c|c|}
\hline \multicolumn{8}{|c|}{ Weeks } \\
\hline 1 & 2 & 3 & 4 & 5 & 6 & 7 & 8 \\
\hline \multicolumn{8}{|c|}{ LD 50 (millions) } \\
\hline 32 & 5.5 & $4 \cdot 1$ & $3 \cdot 1$ & $3 \cdot 1$ & $2 \cdot 1$ & $\mathbf{2} \cdot \mathbf{1}$ & $1 \cdot 0$ \\
\hline 83 & 38 & 10 & 7 & 4 & $\mathbf{3}$ & 0.9 & $0 \cdot 6$ \\
\hline 180 & 62 & 23 & 17 & 10 & 10 & 10 & 10 \\
\hline 194 & 170 & 160 & 122 & 122 & 122 & 122 & 108 \\
\hline
\end{tabular}

and it was found that although the strains were tested as soon as possible after being received at Elstree, nevertheless some days had often elapsed between swabbing and the mouse test. For instance, strain $\mathrm{C} 978$ was received 12 days after swabbing, and a suitable subculture for infecting mice could not be prepared until 3 days later-a delay of 15 days.

As it was possible that some form of degeneration might occur in this period, an arrangement was made with the Central Public Health Laboratory, Colindale, to collect special cough-plates, to subculture at once and to use this subculture to infect mice at the earliest possible time after collection of the cough-plate from the patient. Seven strains were collected and used. These cultures showed considerable variation in virulence (Table 7). It is therefore assumed that these variations reflect inherent characters of $\boldsymbol{H}$. pertussis strains. At present we do not know enough to explain these variations in mouse 
virulence of strains which have all been isolated from patients with clinical whooping-cough.

Table 5. LD50 of the first series of twenty-five strains of Haemophilus pertussis tested for virulence

Calculated each week for 8 weeks.

\begin{tabular}{llllllll}
\multicolumn{8}{c}{ Week } \\
\hline 1 & 2 & 3 & 4 & 5 & 6 & 7 & 8
\end{tabular}

Strain of

H. pertussis



Table 6. Repeated virulence tests to show reproducibility of results

$\begin{array}{cccc}\text { Strain of } \mathrm{H} \text {. pertussis } & \begin{array}{c}\text { No. of } \\ \text { subculture }\end{array} & \text { Date of test } & \begin{array}{c}\text { LD 50 (millions), } \\ \text { 28th day }\end{array} \\ \text { C407 } & 3 & 19 . \text { vii. } 48 & 0 \cdot 24 \\ & 3 & \text { 19. vii. } 48 & 0 \cdot 28 \\ \text { C7386 } & 3 & 19 . \text { vii. } 48 & 0 \cdot 33 \\ & 3 & 13 . \text { viii. } 48 & 26 \cdot 0 \\ \text { C10487 } & 3 & 13 . \text { viii. } 48 & 28 \cdot 0 \\ 407 P & 3 & 13 . \text { viii. } 48 & 29 \cdot 3 \\ & 2 & 9 . \text { iv. } 49 & 0 \cdot 67 \\ & 2 & 9 . \text { jv. } 49 & 0 \cdot 65 \\ & 3 & 19 . \text { vii. } 48 & 0 \cdot 33 \\ & 4 & 20 . \text { vii. } 48 & 0 \cdot 28 \\ & 5 & 21 . \text { vii. } 48 & 0 \cdot 37\end{array}$

The distribution of strains in order of virulence in the various tests is shown in Table 8. 
Table 7. LD50 of strains of Haemophilus pertussis (2nd subculture) tested in mice within $48 \mathrm{hr}$. of taking the swab

$\begin{array}{ccc}\text { Strain of } H \text {. pertussis } & \text { LD 50 (millions) } & \begin{array}{c}\text { Quick-killing } \\ \text { factor }\end{array} \\ \text { C2843 } & 35 \cdot 0 & - \\ \text { C2476 } & 0 \cdot 66 & + \\ \text { C4039 } & 0 \cdot 58 & + \\ \text { C4491 } & 30 \cdot 0 & + \\ \text { C6403 } & 51 \cdot 0 & - \\ \text { C 7383 } & 3 \cdot 75 & - \\ \text { C10487 } & 0 \cdot 67 & +\end{array}$

Table 8. Classification of strains of $\mathrm{H}$. pertussis according to LD50

\begin{tabular}{|c|c|c|c|c|c|c|}
\hline \multicolumn{2}{|c|}{$\begin{array}{l}\text { Series } \\
\text { Subculture tested }\end{array}$} & $\begin{array}{c}1 \\
2-22\end{array}$ & $\stackrel{2}{2}$ & $\begin{array}{l}3 \\
2\end{array}$ & $\begin{array}{r}4 \\
2-8\end{array}$ & Total* \\
\hline \multicolumn{7}{|c|}{ LD50 (millions) } \\
\hline $\mathbf{A}$ & $<1.0$ & 3 & 10 & $\mathbf{3}$ & 15 & 42 \\
\hline B & 1.0 and $<5.0$ & 2 & 6 & 1 & 10 & 19 \\
\hline C & $5 \cdot 0$ and $<25 \cdot 0$ & 6 & 9 & 0 & 7 & 22 \\
\hline D & 25.0 and $<125.0$ & 12 & 10 & 3 & 10 & 35 \\
\hline \multirow[t]{2}{*}{$\mathbf{E}$} & $>125 \cdot 0$ & 2 & $\mathbf{1}$ & $\mathbf{0}$ & $\mathbf{0}$ & 3 \\
\hline & Total & 25 & 36 & 7 & 42 & 121 \\
\hline
\end{tabular}

\section{Quick-killing factor (q.k.f.)}

Another phenomenon was observed: the method of titrating virulence by the LD50 depends on the total number of mice killed at the different dose levels and ignores the time taken to kill; when, however, time to death is taken into account it is seen that two strains of equal LD50 may differ considerably (Table 9 ).

The difference is most obvious at the $100 \times 10^{6}$ dose level, where the average time of death was 2.0 days for strain L 33 and 8.9 days for strain L 9, though the LD 50 for these strains was $\mathbf{0 . 5 5}$ and 0.5 respectively; similarly, in strain G941 the average time of death was 4.7 days and in strain L 46, 13.1 days.

The presence or absence of the quick-killing factor was indicated by the number of mice killed in 3 days at the $100 \times 10^{6}$ dose level; if more than half the mice were killed the strain was considered positive for q.k.f.; if less than half, negative. The distinction between the two kinds of strain is usually quite clear and is usually reflected at the $10 \times 10^{6}$ dose level (Table 10).

Little more was discovered about the q.k.f. except that it could be lost when the strain was subcultured too long and recovered by mouse passage up to a point, after which it was permanently lost. The time at which this loss took place differed with the strain. Some preliminary experiments indicated that the q.k.f. is probably not antigenic, as demonstrated by the usual methods. Vaccines prepared from q.k.f. positive strains are not markedly superior to vaccines prepared from q.k.f. negative strains, when tested by Kendrick's method (Kendrick et al., 1947). 
Table 9. Variation in time of death of mice caused by different strains of Haemophilus pertussis at the same dose level

\begin{tabular}{|c|c|c|c|c|c|c|c|c|c|c|}
\hline \multirow{2}{*}{$\begin{array}{l}\text { Strain of } \\
\text { H. pertussis } \\
\text { L33 }\end{array}$} & \multirow{2}{*}{$\begin{array}{c}\begin{array}{c}\text { Dose } \\
\text { (millions) }\end{array} \\
100 \\
10 \\
1 \\
0 \cdot 1\end{array}$} & \multicolumn{7}{|c|}{ Period to death in ten mice (days) } & \multirow{2}{*}{ 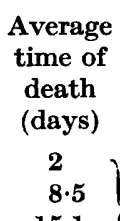 } & \multirow{2}{*}{$\begin{array}{c}\text { LD50 } \\
\text { (28th day) } \\
\text { (millions) } \\
\quad 0.55\end{array}$} \\
\hline & & $\begin{array}{rr}2 & 2 \\
2 & 2 \\
11 & 13 \\
13 & 15\end{array}$ & $\begin{array}{rr}2 & 2 \\
2 & 4 \\
14 & 16 \\
19 & 20\end{array}$ & $\begin{array}{r}2 \\
6 \\
16 \\
20\end{array}$ & $\begin{array}{c}2 \\
19 \\
21 \\
20\end{array}$ & $\begin{array}{cc}2 & 2 \\
20 & 21 \\
S & 5 \\
S\end{array}$ & $\begin{array}{ll}2 & 2 \\
21 & \mathrm{~S} \\
\mathrm{~S} & \mathrm{~S} \\
\mathrm{~S} & \mathrm{~S}\end{array}$ & $\begin{array}{l}2 \\
S \\
S \\
S\end{array}$ & & \\
\hline $\mathbf{L} \boldsymbol{\theta}$ & $\begin{array}{c}100 \\
10 \\
1 \\
0 \cdot 1\end{array}$ & $\begin{array}{rr}4 & 7 \\
6 & 11 \\
13 & 14 \\
18 & 22\end{array}$ & $\begin{array}{rr}7 & 8 \\
13 & 13 \\
16 & 17 \\
28 & 28\end{array}$ & $\begin{array}{r}9 \\
14 \\
18 \\
28\end{array}$ & $\begin{array}{rr}9 & 1 \\
16 & 2 \\
18 & 2 \\
S & \end{array}$ & $\begin{array}{ll}10 & 10 \\
24 & 5 \\
20 & 22 \\
S & 5\end{array}$ & $\begin{array}{rr}10 & 12 \\
S & S \\
22 & 28 \\
S & S\end{array}$ & $\begin{array}{r}13 \\
a \\
\mathrm{~S} \\
\mathrm{~S}\end{array}$ & $\begin{array}{r}8.9 \\
13.8 \\
18.4 \\
24.8\end{array}$ & 0.5 \\
\hline G941 & $\begin{array}{c}100 \\
10 \\
1 \\
0 \cdot 1\end{array}$ & $\begin{array}{rr}2 & 2 \\
5 & 6 \\
5 & 21 \\
\text { S } & \text { S }\end{array}$ & $\begin{array}{ll}2 & 2 \\
6 & 9 \\
\text { S } & \text { S } \\
\text { S } & \text { S }\end{array}$ & $\begin{array}{l}\mathbf{2} \\
\mathbf{9} \\
\mathrm{S} \\
\mathrm{S}\end{array}$ & 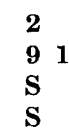 & $\begin{array}{r}2 \\
11 \\
\mathrm{~S} \\
\mathrm{~S}\end{array}$ & $\begin{array}{ll}3 & 7 \\
\mathrm{~S} & \mathrm{~S} \\
\mathrm{~S} & \mathrm{~S} \\
\mathrm{~S} & \mathrm{~S}\end{array}$ & $\begin{array}{r}23 \\
S \\
S \\
S\end{array}$ & $\begin{array}{r}4 \cdot 7 \\
7 \cdot 8 \\
13 \cdot 0 \\
-\end{array}$ & $6 \cdot 4$ \\
\hline $\mathbf{L 4 6}$ & $\begin{array}{r}100 \\
10 \\
1 \\
0 \cdot 1\end{array}$ & $\begin{array}{rr}6 & 7 \\
10 & 12 \\
5 & S \\
23 & S\end{array}$ & $\begin{array}{rr}7 & 9 \\
13 & 15 \\
\text { S } & S \\
\text { S } & \text { S }\end{array}$ & $\begin{array}{r}11 \\
17 \\
S \\
S\end{array}$ & $\begin{array}{cc}17 & 1 \\
20 \\
S \\
S\end{array}$ & $\begin{array}{c}18 \\
\mathrm{~S} \\
\mathrm{~S} \\
\mathrm{~S}\end{array}$ & $\begin{array}{lr}20 & 23 \\
\text { S } & S \\
S & S \\
S & S\end{array}$ & $\begin{array}{l}S \\
S \\
S \\
S\end{array}$ & $\begin{array}{c}13 \cdot 1 \\
14 \cdot 5 \\
-\end{array}$ & $8 \cdot 3$ \\
\hline L 14 & $\begin{array}{r}100 \\
10 \\
1 \\
0 \cdot 1\end{array}$ & $\begin{array}{rr}\mathbf{2} & \mathbf{2} \\
\mathbf{4} & \mathbf{5} \\
\mathbf{2 2} & \mathbf{S} \\
\mathbf{9} & \mathbf{S}\end{array}$ & $\begin{array}{rr}2 & 3 \\
7 & 18 \\
S & S \\
S & S\end{array}$ & $\begin{array}{r}7 \\
19 \\
\text { S } \\
\text { S }\end{array}$ & $\begin{array}{l}\mathbf{S} \\
\mathbf{S} \\
\mathbf{S} \\
\mathbf{S}\end{array}$ & $\begin{array}{l}\mathbf{S} \\
\mathbf{S} \\
\mathbf{S} \\
\mathbf{S}\end{array}$ & $\begin{array}{ll}\mathbf{S} & \mathbf{S} \\
\mathbf{S} & \mathbf{S} \\
\mathbf{S} & \mathbf{S} \\
\mathbf{S} & \mathbf{S}\end{array}$ & $\begin{array}{l}\mathbf{S} \\
\mathbf{S} \\
\mathbf{S} \\
\mathbf{S}\end{array}$ & $\begin{array}{c}3 \cdot 2 \\
10 \cdot 6 \\
- \\
-\end{array}$ & $36 \cdot 0$ \\
\hline C5467 & $\begin{array}{c}100 \\
10 \\
1 \\
0 \cdot 1\end{array}$ & $\begin{array}{rr}4 & 9 \\
15 & 20 \\
\mathrm{~S} & \mathrm{~S} \\
\mathrm{~S} & \mathrm{~S}\end{array}$ & $\begin{array}{rr}9 & 12 \\
21 & 26 \\
S & S \\
S & S\end{array}$ & $\begin{array}{r}15 \\
5 \\
S \\
S\end{array}$ & $\begin{array}{c}171 \\
S \\
S \\
S\end{array}$ & $\begin{array}{r}17 \\
\mathrm{~S} \\
\mathrm{~S} \\
\mathrm{~S}\end{array}$ & $\begin{array}{ll}21 & S \\
S & S \\
S & S \\
S & S\end{array}$ & $\begin{array}{l}\text { S } \\
\text { S } \\
\text { S } \\
\text { S }\end{array}$ & $\begin{array}{c}13 \cdot 0 \\
20.5 \\
- \\
-\end{array}$ & $\mathbf{3 5 \cdot 0}$ \\
\hline
\end{tabular}

Table 10. Strains of Haemophilus pertussis tested for quick-killing factor, classified according to virulence

\begin{tabular}{|c|c|c|c|c|c|c|c|}
\hline \multicolumn{2}{|c|}{ Quick-killing factor: $\ldots$} & \multirow{2}{*}{\multicolumn{2}{|c|}{$+\underset{\text { All-strains }}{-}$}} & \multirow{2}{*}{\multicolumn{2}{|c|}{$\stackrel{+}{\text { 2nd-3rd subcultures }}$}} & \multirow{2}{*}{\multicolumn{2}{|c|}{$\stackrel{+}{-}-$}} \\
\hline Group & LD 50 (millions) & & & & & & \\
\hline $\mathbf{A}$ & $<1.0$ & 20 & 11 & 4 & 6 & $\mathbf{3}$ & $\mathbf{0}$ \\
\hline B & 1.0 and $<5.0$ & 8 & 8 & 2 & 4 & $\mathbf{0}$ & 1 \\
\hline $\mathbf{C}$ & 5.0 and $<25.0$ & 6 & 8 & 4 & $\mathbf{5}$ & $\mathbf{0}$ & $\mathbf{0}$ \\
\hline $\mathrm{D}$ & 25.0 and $<125.0$ & 1 & 15 & 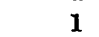 & 8 & 1 & 2 \\
\hline $\mathbf{E}$ & $>125 \cdot 0$ & $\mathbf{0}$ & 2 & 0 & 1 & $\mathbf{0}$ & $\mathbf{0}$ \\
\hline
\end{tabular}

\section{Correlation of mouse virulence with other factors}

The following factors were tested for correlation with mouse virulence (LD 50) or with the q.k.f. : (a) viable count; (b) toxin content; (c) haemagglutinin of Keogh \& North (1948); $(d)$ 'age' of culture in terms of number of daily


challenge; $(f)$ duration of illness when swab was taken; $(g)$ type of swab, prenasal or postnasal. 
Since suspensions used in virulence tests are made up by opacity (total count) and since it is probable that the ratio total count:viable count varies from strain to strain and from suspension to suspension of one strain, it is possible that suspensions which contain the highest proportion of viable organisms might be the most virulent. Toxin was an obvious factor to be investigated in relation to the q.k.f., because the time and type of death suggest toxin, from its known characters. Keogh \& North (1948) have shown that their haemagglutinin is antigenic and they suggest that it is intimately connected with virulence. Its nature and function in relation to virulence, etc. are not yet clearly understood. Gray (1946) pointed out the importance of the 'physiological age' of a culture and it may be that the 'age' of the culture in terms of the number of subcultures from the original plate is important, though this might affect the LD50 and q.k.f. independently, particularly in cultures which degenerate rapidly. It has been suggested by Evans (1949) that the kind of organism isolated from prenasal swabs differs in growth and morphology from organisms isolated from postnasal swabs or cough-plates. If this is so, they might also differ in virulence. Toomey, Ranta \& Takacs (1935) showed that a less virulent form of organism may be found in the throats of patients in the later stages of the disease. It was not possible to test all strains for each of the above factors; only a representative sample of strains could be tested for each.

\section{(a) Viable count and virulence}

Certain cultures were counted by the method of Miles \& Misra (1938). As will be seen in Table 11, there is apparently no correlation between the viable count and the LD 50, nor between the viable count and the q.k.f. By chance, most of the strains tested in this group were of high virulence and only two strains were q.k.f. negative.

Table 11. Comparison of virulence (LD50) and viable count

\begin{tabular}{lccccc} 
Strain of & \multicolumn{2}{c}{ Count (millions) } & \multicolumn{2}{c}{ LD 50 (millions) calculated on } \\
\cline { 2 - 3 } H. pertussis & Total & Viable & $\begin{array}{c}\text { Ratio, } \\
\text { total:viable }\end{array}$ & Total count & Viable count \\
G1127 & 100 & 108 & $0 \cdot 9$ & $0 \cdot 2$ & $0 \cdot 22$ \\
L 16 & 100 & 88 & $1 \cdot 14$ & $4 \cdot 1$ & $3 \cdot 61$ \\
L14 & 100 & 75 & $1 \cdot 33$ & $36 \cdot 0$ & $27 \cdot 0$ \\
G1127-3 & 100 & 72 & $1 \cdot 39$ & $0 \cdot 1$ & $0 \cdot 07$ \\
L15 & 100 & 71 & $1 \cdot 41$ & $7 \cdot 5$ & $5 \cdot 3$ \\
C4576 & 100 & 56 & $1 \cdot 78$ & $0 \cdot 4$ & $0 \cdot 22$ \\
L20 & 100 & 40 & $2 \cdot 5$ & $2 \cdot 7$ & $1 \cdot 08$ \\
L21 & 100 & 40 & $2 \cdot 5$ & $9 \cdot 4$ & $3 \cdot 76$ \\
G863-3 & 100 & 34 & $2 \cdot 94$ & $0 \cdot 55$ & $0 \cdot 19$ \\
L22 & 100 & 20 & $5 \cdot 0$ & $67 \cdot 0$ & $13 \cdot 4$ \\
G863-2 & 100 & 18 & $5 \cdot 56$ & $1 \cdot 0$ & $0 \cdot 18$
\end{tabular}

\section{(b) Toxin and virulence}

Five strains were tested for toxin by the intravenous route in mice at the same time that they were tested for virulence by the standard method (Table 12). Though the LD50 varied considerably there was little difference in the toxin titre; there was also no correlation between toxin and q.k.f. This 
result bears out the findings of Cruickshank \& Freeman (1937) who tested twenty-one strains by the intraperitoneal route, and found that the M.L.D. was remarkably constant in seventeen strains, being $6000 \times 10^{6}-9000 \times 10^{6}$. We now know that the intraperitoneal route as used by Cruickshank measures toxin.

Table 12. Comparison of virulence (LD50) and toxigenicity in five strains of Haemophilus pertussis (2nd subculture)

$\begin{array}{lccc}\begin{array}{c}\text { Strain of } \\ \text { H. } \text { pertussis }\end{array} & \begin{array}{c}\text { Virulence LD50 } \\ \text { (millions) }\end{array} & \begin{array}{c}\text { Toxin, LD50 } \\ \left.\text { (millions } \times 10^{3}\right)\end{array} & \begin{array}{c}\text { Quick-killing } \\ \text { factor }\end{array} \\ \text { C4576 } & 0 \cdot 4 & 5 \cdot 4 & + \\ \text { L13 } & \mathbf{3 \cdot 6} & 2 \cdot 0 & - \\ \text { C5146 } & 6 \cdot 2 & 3 \cdot 6 & + \\ \text { C5467 } & \mathbf{3 5 \cdot 0} & 4 \cdot 8 & - \\ \text { L14 } & \mathbf{3 6 \cdot 0} & \mathbf{3 \cdot 6} & +\end{array}$

In another experiment toxin titrations were carried out in rabbits with similar results; there was no correlation between the toxicity of the strain as measured intradermally in rabbits and the virulence or the q.k.f. titrated intranasally in mice.

\section{(c) Haemagglutinin and virulence}

As Keogh \& North (1948) have suggested that their haemagglutinating factor is intimately connected with virulence, the haemagglutination titre was tested in a number of strains when they were tested for virulence.

Method. Suspensions for the haemagglutination test were prepared in saline or Casamino acid and standardized to contain $10,000 \times 10^{6}$ organisms $/ \mathrm{ml}$., and serial twofold dilutions were prepared from these suspensions.

Red blood cells were prepared by centrifuging $1 \mathrm{ml}$. of fowl's blood, washing the red blood cells (r.b.c.) three times in saline and re-suspending in $50 \mathrm{ml}$. of saline. This 'strong' suspension can be kept 3 or 4 days in the refrigerator; before use it is diluted $1 / 4$ with $0.85 \%$ saline. It was found that $0.5 \mathrm{ml}$. of this dilute suspension when added to $\mathbf{0 . 2 5} \mathrm{ml}$. of bacterial suspension gave the optimum amount of red cells. The exact quantity of red cells did not affect the titre as long as there were not too few cells to give a clear positive and not too many to mask a weak positive.

For the test $\mathbf{0 . 2 5} \mathrm{ml}$. of the dilution of bacterial suspension was placed in a $12 \mathrm{~mm} . \times 55 \mathrm{~mm}$. tube and $0.5 \mathrm{ml}$. of r.b.c. suspension added. The racks were shaken and incubated at $37^{\circ}$ for $1 \mathrm{hr}$. The tubes were then shaken and put in the refrigerator to allow the cells to settle before the test was read; shaking after incubation and settling in the refrigerator gave a more distinct end-point. The test could be read at any time after $2-30 \mathrm{hr}$. in the refrigerator without any modification of the end-point. The end-point is taken as the reciprocal of the final dilution of bacterial suspension.

It was not possible to estimate haemagglutinin on all strains. Strains therefore fall into two groups: (1) strains in which the suspension used for the virulence test was tested for haemagglutination; (2) strains in which other 
subcultures were tested for haemagglutinin. With some strains, subcultures in both groups were tested.

The virulence test suspensions in $\S 1$ of Table 13 were grown for $20 \mathrm{hr}$. on Bordet-Gengou media in all cases. In $\S 2$ the average titres shown were from subcultures grown either on solid or liquid media from $24 \mathrm{hr}$. to 5 days.

Table 13. Numbers of strains of Haemophilus pertussis tested for
haemagglutinin classified according to mouse virulence (LD50)
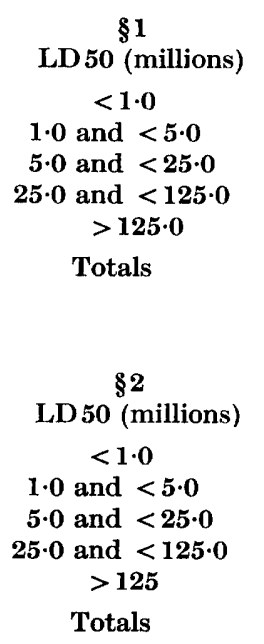

\begin{tabular}{cccccc}
\multicolumn{5}{c}{ Haemagglutinin titres of virulence test suspensions } \\
\hline $192-96$ & $48-24$ & 12 & $\pm 12- \pm 6$ & 0 & Totals \\
2 & 4 & 3 & 2 & 3 & 14 \\
. & 6 & 1 &. & 4 & 11 \\
1 & 4 & 2 & 1 & 2 & 10 \\
1 & 3 & 3 &. & 2 & 9 \\
. & 1 &. &. &. & 1 \\
4 & 18 & 9 & 3 & 11 & 45
\end{tabular}

Average haemagglutinin titres of suspensions other than virulence test suspensions

All Phase I strains may produce haemagglutinin under suitable conditions; of the sixty-eight strains tested, eleven never produced haemagglutinin and the remaining fifty-seven strains produced it fairly regularly. There were a few occasions on which haemagglutinin was not produced when expected, but this was possibly due to faulty media. Of the eleven virulence test suspensions which were negative for haemagglutinin, the stock strains of seven were positive or trace when tested on other occasions, and four were always negative. Of the eleven negative strains in $§ 2$, one strain was positive in two different suspensions and negative in ten other suspensions, the other ten strains were invariably negative; their LD 50 varied from $0 \cdot 1$ to $86 \cdot 0$ million.

Table 14 shows in greater detail the characteristics of some typical strains from each section. It will be seen that there is little correlation between the haemagglutinin titre and either the LD 50 or the q.k.f. It must be borne in mind that the titre of haemagglutinin in vitro may not be a measure of the activity (if any) of this factor in vivo.

(d) Age of culture when tested, in terms of number of subcultures, and virulence

The age of the culture, in terms of the number of subcultures between the original swab plate culture and the actual culture used for the mouse challenge, was investigated, since there is evidence that cultures decline in virulence on subculture in the laboratory and may do so at different rates. Of the thirteen 
strains tested on more than one occasion, seven remained stable for virulence over the period of test, and six proved to be unstable.

Table 14. Comparison of haemagglutinin and virulence (LD50) in a number of strains of Haemophilus pertussis

\begin{tabular}{|c|c|c|c|c|c|}
\hline $\begin{array}{l}\text { Strain of } \\
\text { H. pertussis }\end{array}$ & $\begin{array}{c}\text { No. of } \\
\text { subcultures }\end{array}$ & $\begin{array}{l}\text { Haem- } \\
\text { agglutinin titre } \\
\text { of mouse } \\
\text { challenge } \\
\text { suspension }\end{array}$ & LD50 & $\begin{array}{l}\text { Quick-killing } \\
\text { factor }\end{array}$ & $\begin{array}{c}\text { Average } \\
\text { haemagglutinin } \\
\text { production } \\
\text { of other } \\
\text { suspensions }\end{array}$ \\
\hline $\begin{array}{l}\text { G } 863 \\
\text { G962 }\end{array}$ & $\begin{array}{l}\mathbf{6} \\
\mathbf{5}\end{array}$ & $\begin{array}{l}192 \\
192\end{array}$ & $\begin{array}{c}0 \cdot 66 \\
77 \cdot 0\end{array}$ & - & $\underset{\text { NT }}{++}$ \\
\hline $\begin{array}{l}\text { L 11 } \\
\text { L45 }\end{array}$ & $\begin{array}{r}3 \\
22\end{array}$ & $\begin{array}{l}96 \\
96\end{array}$ & $\begin{array}{l}0.75 \\
9 \cdot 4\end{array}$ & $\begin{array}{l}+ \\
-\end{array}$ & $\begin{array}{l}++ \\
\text { NT }\end{array}$ \\
\hline $\begin{array}{l}\text { L } 12 \\
\text { L46 } \\
\text { G 894 } \\
\text { L 14 } \\
\text { G 959 }\end{array}$ & $\begin{array}{r}3 \\
\mathbf{2 2} \\
- \\
-2 \\
\mathbf{2} \\
7\end{array}$ & $\begin{array}{l}48 \\
48 \\
48 \\
48 \\
48\end{array}$ & $\begin{array}{c}0 \cdot 1 \\
8 \cdot 67 \\
9 \cdot 3 \\
\mathbf{3 6 \cdot 0} \\
\mathbf{5 5 \cdot 0}\end{array}$ & $\begin{array}{l}+ \\
+ \\
+ \\
+ \\
+\end{array}$ & $\begin{array}{c}+++ \\
\text { NT } \\
++ \\
+++ \\
+++\end{array}$ \\
\hline $\begin{array}{l}\text { L54 } \\
\text { L16 } \\
\text { C5146 } \\
\text { G992 } \\
\text { G947 }\end{array}$ & $\begin{array}{l}9 \\
2 \\
2 \\
4 \\
6\end{array}$ & $\begin{array}{l}\mathbf{2 4} \\
\mathbf{2 4} \\
\mathbf{2 4} \\
\mathbf{2 4} \\
\mathbf{2 4}\end{array}$ & $\begin{array}{r}1 \cdot 7 \\
4 \cdot 1 \\
6 \cdot 2 \\
42 \cdot 0 \\
143 \cdot 0\end{array}$ & $\begin{array}{l}+ \\
+ \\
+ \\
- \\
-\end{array}$ & $\begin{array}{c}\text { NT } \\
+++ \\
++ \\
+ \\
++\end{array}$ \\
\hline $\begin{array}{l}\text { L45 } \\
\text { L15 } \\
\text { G978 } \\
\text { L2 } \\
\text { G983 }\end{array}$ & $\begin{array}{l}\mathbf{5} \\
\mathbf{2} \\
\mathbf{2} \\
\mathbf{2} \\
\mathbf{4}\end{array}$ & $\begin{array}{l}12 \\
12 \\
12 \\
12 \\
12\end{array}$ & $\begin{array}{c}0 \cdot 64 \\
7 \cdot 5 \\
17 \cdot 0 \\
40 \cdot 0 \\
100 \cdot 0\end{array}$ & $\begin{array}{l}+ \\
+ \\
- \\
- \\
-\end{array}$ & $\begin{array}{c}\text { NT } \\
+++ \\
\pm \\
+ \\
\pm\end{array}$ \\
\hline $\begin{array}{l}\text { C4576 } \\
\text { L49 }\end{array}$ & $\begin{array}{r}2 \\
10\end{array}$ & $\begin{array}{l} \pm 12 \\
\pm 12\end{array}$ & $\begin{array}{l}0.4 \\
0 \cdot 84\end{array}$ & $\begin{array}{l}+ \\
+\end{array}$ & $\stackrel{++}{\text { NT }}$ \\
\hline $\begin{array}{l}\text { G1101 } \\
\text { G1144 } \\
\text { C3627 } \\
\text { L7 }\end{array}$ & $\begin{array}{l}\mathbf{3} \\
\mathbf{2} \\
\mathbf{2} \\
\mathbf{4}\end{array}$ & $\begin{array}{l}\mathbf{0} \\
\mathbf{0} \\
\mathbf{0} \\
\mathbf{0}\end{array}$ & $\begin{array}{c}0 \cdot 55 \\
0 \cdot 75 \\
3 \cdot 8 \\
10 \cdot 0\end{array}$ & $\begin{array}{l}- \\
- \\
-\end{array}$ & $\begin{array}{l}\mathbf{0} \\
\mathbf{0} \\
\mathbf{0} \\
\mathbf{0}\end{array}$ \\
\hline $\begin{array}{l}\text { L17 } \\
\text { L10 } \\
\text { L20 } \\
\text { G894 } \\
\text { L21 } \\
\text { L18 }\end{array}$ & $\begin{array}{l}\mathbf{2} \\
\mathbf{3} \\
\mathbf{3} \\
\mathbf{2} \\
\mathbf{3} \\
\mathbf{2}\end{array}$ & $\begin{array}{l}\mathbf{0} \\
\mathbf{0} \\
\mathbf{0} \\
\mathbf{0} \\
\mathbf{0} \\
\mathbf{0}\end{array}$ & $\begin{array}{r}0 \cdot 7 \\
1 \cdot 0 \\
2 \cdot 7 \\
8 \cdot 0 \\
9 \cdot 4 \\
56 \cdot 0\end{array}$ & $\begin{array}{l}- \\
- \\
+ \\
- \\
+ \\
-\end{array}$ & $\begin{array}{c}++ \\
\pm \\
++ \\
+++ \\
++ \\
++\end{array}$ \\
\hline $\begin{array}{l}\text { G } 1096 \\
\text { C } 15 S \\
\text { G1016 } \\
\text { G1030 } \\
\text { L3 }\end{array}$ & $\begin{array}{l}3 \\
3 \\
2 \\
2 \\
2 \\
2\end{array}$ & $\begin{array}{l}\text { NT } \\
\text { NT } \\
\text { NT } \\
\text { NT } \\
\text { NT }\end{array}$ & $\begin{array}{c}0 \cdot 1 \\
0 \cdot 46 \\
0 \cdot 85 \\
6 \cdot 4 \\
86 \cdot 0\end{array}$ & $\begin{array}{l}+ \\
- \\
- \\
-\end{array}$ & $\begin{array}{l}\mathbf{0} \\
\mathbf{0} \\
\mathbf{0} \\
\mathbf{0} \\
\mathbf{0}\end{array}$ \\
\hline
\end{tabular}

Haemagglutinin production:,+++ 96 or 192 or more;,++ 24 or $48 ;+, 12 ; \pm, \pm 12$ or $\pm 6 ; 0, \pm 3$ or 0 . NT, not tested.

In Table 15 details of a selection of strains of the two types are shown. The degeneration in respect to this one characteristic is obvious in the two 'unstable' strains. Of the 'stable' strains L 58 remained constant for virulence for 132 daily subcultures, and L 57 for seventy-two. Strain L 49 remained reason- 
Table 15. Virulence of cultures of Haemophilus pertussis subcultured daily on to fresh Bordet-Gengou medium

Strain of

LD 50 (millions) after varying numbers of subcultures shown

H. pertussis

$\begin{array}{llccc}\text { L45 } & 0.64(5) & 9 \cdot 4(22) & 34 \cdot 0(48) & 65.0(58) \\ \text { L46 } & 0 \cdot 67(5) & 8 \cdot 3(22) & 66.0(39) & \cdot \\ \text { L49 } & 0.8(5) & 0.84(10) & 3.0(62) & 26.0(161) \\ \text { L57 } & 0 \cdot 17(2) & 0.84(72) & \cdot & \cdot \\ \text { L58 } & 9 \cdot 3(6) & 10.0(132) & \cdot & \cdot\end{array}$

ably virulent for about sixty-two subcultures, but when next tested, at the 161st subculture, showed some degeneration.

There is no evidence that LD 50 or q.k.f. depends simply on the number of times the strain has been subcultured.

Table 16. Classification of strains of Haemophilus pertussis according to virulence (LD 50) and number of subcultures tested



Group LD50 (millions)

No. of strains in the various groups

(a) Forty-five strains subcultured at daily intervals

$\begin{array}{lcrrrrrrrrrrrrrrrrrr}\text { A } & <1 & 4 & 3 & 2 & 1 & . & . & . & 1 & . & 1 & . & . & . & 1 & 1 & 1 & 15 \\ \text { B } & 1 \text { and }<5 & 3 & 3 & 1 & . & . & . & 1 & 2 & . & . & . & 1 & . & . & . & . & 11 \\ \text { C } & 5 \text { and }<25 & 7 & 1 & 2 & . & . & . & . & . & . & . & . & 1 & . & . & . & . & 11 \\ \text { D } & 25 \text { and }<125 & 4 & 1 & . & . & . & . & . & . & . & . & . & . & . & . & . & . & 1 \\ \text { E } & >125 & . & . & . & . & . & . & . & . & . & 1 & 2 & . & . & . & . & . & 8 \\ & \text { Totals } & & 18 & 8 & 5 & 1 & 0 & 0 & 1 & 3 & 0 & 2 & 2 & 2 & 0 & 1 & 1 & 1 & 45\end{array}$

(b) Forty-eight strains subcultured irregularly or at more than daily intervals

\begin{tabular}{|c|c|c|c|c|c|c|c|c|c|c|c|c|c|c|c|c|c|c|}
\hline $\mathbf{A}$ & $<1$ & $\mathbf{3}$ & 8 & 2 & 2 & 2 & . & 2 & & 1 & 1 & . & 1 & . & . & . & . & 22 \\
\hline B & 1 and $<5$ & 2 & 1 & 1 & - & $\cdot$ & . & . & 1 & $\cdot$ & • & & - & $\cdot$ & • & . & . & $\mathbf{5}$ \\
\hline C & 5 and $<\mathbf{2 5}$ & 2 & 5 & 2 & . & 1 & . & . & • & . & & & & 2 & & . & - & 12 \\
\hline D & 25 and $<125$ & $\mathbf{3}$ & . & 3 & 1 & 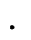 & 1 & . & & . & • & $\cdot$ & • & . & . & . & - & 8 \\
\hline $\mathbf{E}$ & $>125$ & - & • & - & • & 1 & & . & & . & $\cdot$ & & • & . & $\cdot$ & . & - & 1 \\
\hline & & 10 & 14 & 8 & 3 & 4 & 1 & 2 & 1 & 1 & 1 & 0 & 1 & 2 & 0 & 0 & 0 & 8 \\
\hline
\end{tabular}

Table 16 shows the numbers of strains tested at each subculture arranged in the five groups according to the LD 50. In all, ninety-three strains were tested; forty-five strains subcultured at daily intervals and forty-eight at longer or irregular intervals. Fifteen of the forty-five strains, which had been subcultured daily (Table 16, part 1), were found to be in Group A, having an LD 50 of less than $1 \times 10^{6}$. Of these, four were tested at the 2 nd subculture and one at the 35th subculture, the remainder falling between these extremes. Similarly, twenty-two of the forty-eight strains, subcultured at irregular intervals, coming in Group A, were tested on the 2nd to the 15th subculture. Eighteen strains in the first series and ten in the second tested at the 2nd subculture were divided 
more or less equally between groups A, B, C and D. There is no evidence that the number of subcultures per se has any effect on the LD 50. The assumption is made that strains in Group A have not degenerated.

\section{(e) Lapse of time between onset of disease and virulence}

There is no correlation (Table 17) between virulence for mice as measured by the LD50 and the time elapsed between onset of disease and testing in mice. Except for the special strains mentioned on p. 253, the time between onset and testing varied from 15 to 50 days with the forty-four strains tested. Strains with an LD50 of less than 1 million, which it is assumed will not have degenerated appreciably, ranged from the 20th to the 41 st day.

Table 17. Comparison of virulence (LD50) of Haemophilus pertussis strains and time elapsed from onset of disease to mouse test

Figures in brackets 2nd and 3rd subculture only.

Period between onset of disease and testing of strain in mice (days)

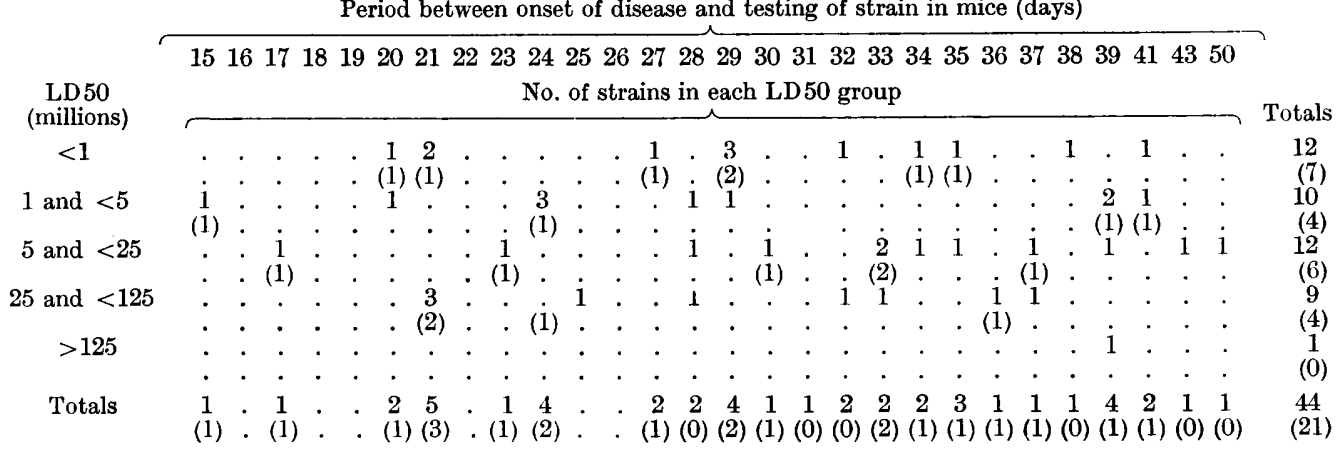

(f) Duration of disease at swabbing and virulence

The same scatter was evident when the duration of the disease at the time of swabbing was compared with the virulence of the strain isolated. Strains of high virulence (Group A: LD 50 less than $1 \cdot 0 \times 10^{6}$ ) were obtained from the 2 nd day to the 21st day, and strains of low virulence (Group D: LD50, $25 \times 10^{6}$ to $125 \times 10^{6}$ ) from the 4 th to the 21 st day. There is no correlation between virulence and duration at least during the first three weeks of the disease.

(g) Type of swab (prenasal or postnasal) and virulence

It has been suggested that there is a difference between strains isolated from prenasal and postnasal swabs, particularly in colonial appearance (Evans, 1949). Though this may be so under certain conditions or on certain media, I have been unable to distinguish between the two and there was no difference in the virulence or the range of virulence of strains isolated by these two methods (Table 18).

\section{DISCUSSION}

Although $H$. pertussis is not a natural pathogen of mice and it is not possible to start an epidemic in mice even under laboratory conditions, mice can be infected artificially. Three main routes have been employed: $(a)$ intraperitoneal 
Table 18. Comparison of virulence (LD50) of Haemophilus pertussis strains and type of swabbing, postnasal or prenasal

\begin{tabular}{|c|c|c|c|c|c|}
\hline \multicolumn{5}{|c|}{ Strains isolated from } & \\
\hline \multicolumn{3}{|c|}{ Postnasal swabs } & \multicolumn{3}{|c|}{ Prenasal swabs } \\
\hline $\begin{array}{l}\text { No. of strain of } \\
H . \text { pertussis }\end{array}$ & $\begin{array}{c}\text { No. of } \\
\text { subculture }\end{array}$ & $\begin{array}{c}\text { LD 50 } \\
\text { (millions) }\end{array}$ & $\begin{array}{l}\text { No. of strain of } \\
\quad H . \text { pertussis }\end{array}$ & $\begin{array}{c}\text { No. of } \\
\text { subculture }\end{array}$ & $\begin{array}{c}\text { LD50 } \\
\text { (millions) }\end{array}$ \\
\hline L9 & 2 & 0.5 & L 12 & $\mathbf{3}$ & $0 \cdot 1$ \\
\hline L 11 & 3 & 0.75 & L 17 & 2 & $0 \cdot 7$ \\
\hline L 10 & 3 & $1 \cdot 0$ & L 33 & 9 & $1 \cdot 0$ \\
\hline G928 & 4 & $3 \cdot 1$ & L 13 & 2 & $3 \cdot 6$ \\
\hline G942 & 3 & $16 \cdot 5$ & L 19 & 2 & $16 \cdot 0$ \\
\hline L3 & 2 & $86 \cdot 0$ & L 18 & 2 & $56 \cdot 0$ \\
\hline G947 & 6 & $143 \cdot 0$ & L 22 & 3 & $67 \cdot 0$ \\
\hline
\end{tabular}

or intravenous; $(b)$ intranasal; $(c)$ intracerebral. Anderson \& North (1943) showed that toxin is involved in the mortality in mice infected intraperitoneally, but it was left to Proom (1947) to clear up the relationship between infection by the intranasal and intraperitoneal routes. Proom showed that death following intraperitoneal injection of $H$. pertussis is due to a toxaemia which can be neutralized by specific antitoxin but not by a pure antibacterial serum, and that there is no evidence of the organism multiplying in the peritoneum or the blood stream. Infection by the intranasal route, first used by Burnet \& Timmins (1937), results in an entirely different picture; something more nearly approaching an infection is obtained. The organisms multiply profusely in the lung and cause a pneumonia similar to that caused by influenza virus, etc. Good descriptions of the condition have been published (Hoyle \& Orr, 1945; Lapin, 1943).

The intracerebral route, first used by Norton \& Dingle (1935) and developed by Kendrick, Elderling, Dixon \& Misner (1947), seems to be dependent on slightly different factors from the other routes, and a reference in Keogh \& North (1948) to some unpublished observations of S. Fisher support this view. It is hoped to investigate these factors in greater detail in this laboratory.

The virulence of $\boldsymbol{H}$. pertussis in mice is a variable and measurable character, and it is a pity that some workers have regarded it as a qualitative factor, a conception doubtless based on the view that Phase $\mathbf{I}$ organisms are virulent and Phase IV organisms avirulent (Leslie \& Gardner, 1931). Virulence can be regarded as qualitative only if an arbitrary standard is set up.

The failure of some earlier workers (Toomey, Ranta \& Takacs, 1935; Strean, 1943), using the intraperitoneal route in guinea-pigs or mice, to enhance the virulence of their strains to any great extent is explained by the work of Evans who reported that toxin production is one of the more stable characteristics of H. pertussis. Cruickshank \& Freeman (1937) support this view; seventeen of their twenty-one freshly isolated strains had an average lethal dose of $6 \times 10^{9}$ $9 \times 10^{9}$ organisms; their mice died usually on the 2 nd-3rd days and rarely after the 5th day. Although it has been shown that death of mice after intraperitoneal injection of living organisms is principally due to the toxin contained in 
the injected organisms, other factors may play some part. It is otherwise difficult to understand the success of some workers (Cruickshank \& Freeman, 1937; Elderling, 1942) in comparing the antigenic potency of different vaccines and the failure of rough vaccines to protect at least some mice.

The following conclusions can be drawn from the experiments reported here:

(1) Consistent and reproducible titrations of virulence can be made in mice by the intranasal route when precautions are taken to standardize procedure and to use mice of the same weight drawn from the same closely bred strain (Tables 1, 2, 3 and 6).

(2) Using mice of the strain C1 kept under the conditions specified, the LD 50 of a number of freshly isolated strains of $H$. pertussis varied from $0 \cdot 1$ to 152 million, calculated by the method of Reed \& Muench on the 28th day. The wide variations in virulence of even the specially collected strains (Table 7) lead one to conclude that these variations in $H$. pertussis strains are true variations in the virulence of the strains, and not an artefact due to degeneration under laboratory conditions. This is not to deny that degeneration under laboratory conditions cannot or does not take place, for it obviously does, more quickly in some strains and more slowly in others. This degeneration or loss of virulence may depend to some extent on the medium employed and will probably vary in rate from one laboratory to another. The presence of this degeneration of pertussis strains is a complicating factor in virulence studies and means that while tests carried out with strains subcultured a few times permit a true evaluation of the virulence of the strain, those carried out on strains subcultured many times may or may not, and it is safe to consider them a true evaluation only in strains of high virulence where degeneration cannot have set in, that is strains in Group A. Strains of moderate virulence may be either strains of true moderate virulence or strains of high virulence which have degenerated to a moderate level; the same is true of strains of low virulence.

The passage of strains through mice and the testing of the virulence of the passaged strain may prove to be the best test for the true virulence of a strain. I found it impossible to enhance the virulence of a strain to any great extent by mouse passage except in the case of certain strains which are known to have lost virulence and in which virulence could be enhanced by mouse passage to a level approximately that of the original culture. Strains which showed the q.k.f. in early subculture but which had lost this factor, can regain it by mouse passage up to a point at which it is, apparently, lost permanently.

(3) Certain strains have the power of killing more rapidly than others (Table 9), though the meaning of this quick-killing factor is not yet understood. The difference between strains with and without this factor is statistically significant (Irwin, 1951, see Note). Preliminary experiments indicate that the q.k.f. is not antigenic. This factor can be lost on serial subculture in the laboratory and can in some cases be regained by mouse passage, but there is apparently a stage after which it is lost permanently; it does not appear possible to 'recover' this factor in strains which did not originally possess it. 
(4) There was no correlation between virulence (LD 50) and the viable count (Table 11) or the toxin content of the suspension used to infect mice (Table 12).

(5) Nor was there any correlation between virulence and haemagglutinin (Tables 13 and 14). Keogh \& North have suggested that the virulence of $H$. pertussis strains is related to their haemagglutinin content and that the strain with the highest haemagglutinin content shows maximal virulence; unfortunately they give details in their protocols of only seven strains. When, however, a number of Phase I organisms are examined it will be seen that virulence and haemagglutinin do not necessarily go hand in hand (Tables 1 and 14). While Keogh \& North's findings are not disputed, it would be more correct to say that while the presence of haemagglutinin is a character of Phase I organisms, within this Phase it may or may not be present and it varies independently of virulence. With regard to toxin and haemagglutinin, it is, of course, possible that their action in vivo is not quite the same as their action in vitro. For example, toxin, which seems to be one of the more stable antigens of $\boldsymbol{H}$. pertussis, might be released by certain strains which undergo autolysis more readily than others on introduction into the lung. This released toxin might act on the lung in some way and allow that strain to become established much more rapidly or successfully. This may equally be possible with haemagglutinin about whose action in vivo we have little information.

(6) There was no obvious correlation between virulence and the history of the strains tested, either in terms of the 'age' of the culture in number of subcultures, or the duration of illness at the time of swabbing, or the type of swab.

(7) There is no doubt that strains degenerate at different rates, and probably that all strains degenerate in time. It is reasonable to suggest that strains in group A-those with an LD 50 of less than $1.0 \times 10^{6}$ - have not degenerated or at any rate have not degenerated to any great extent.

The author is indebted to Dr R. Cruickshank and Dr W. C. Cockburn, Central Public Health Laboratory, Dr R. Knox, Public Health Laboratory Service, Oxford, and Prof. J. W. McLeod, F.R.S., the School of Medicine, Leeds, for the supply of pertussis strains; and to Miss M. P. D. Pile and Miss P. Davies for certain technical assistance.

\section{REFERENCES}

Anderson, G. \& North, E. A. (1943). The relationship of pertussis endotoxin to pertussis immunity in the mouse. Aust. J. exp. Biol. med. Sci. 21, 1.

Burnet, F. M. \& Timmins, C. (1937). Experimental infection with Haemophilus pertussis in the mouse by intranasal inoculation. Brit. J. exp. Path. 18, 83.

Cruickshank, J. C. \& Freeman, G. G. (1937). Immunizing fractions isolated from Haemophilus pertussis. Lancet, ii, 567.

Culotta, C. A., Martin, F. L. \& Liebow, A. A. (1938). Whooping Cough: observations on experimental infection in mice and on attempts at active immunization in mice and in ferrets. Yale J. Biol. Med. 10, 233.

Elderling, G. (1942). A study of the antigenic properties of $\boldsymbol{H}$. pertussis and related organisms. II. Protection tests in mice. Amer. J. Hyg. 36, 294.

Evans, D. (1949). Private communication.

GraY, D. F. (1946). Some factors influencing the virulence of Haemophilus pertussis Phase I. Aust. J. exp. Biol. med. Sci. 24, 301. 
Hoyle, L. \& OrR, J. W. (1945). The histogenesis of experimental pneumonics in mice. J. Path. Bact. 57, 441.

IRwIN, J. O. (1951). Note on the relation between LD50 and average time of death in 25 strains of $\boldsymbol{H}$. pertussis. J. gen. Microbiol. 5, 266.

Kendrick, P. L., Elderling, G., Dixon, M. K. \& Misner, J. (1947). Mouse protection tests in the study of pertussis vaccines. Amer. J. publ. Hlth, 37, 803.

KeOGH, E. V. \& North, E. A. (1948). The haemagglutinin of Haemophilus pertussis. 1. Haemagglutinin as a protective antigen in experimental murine pertussis. Aust. J. exp. Biol. med. Sci. 26, 315.

LAPIN, J. H. (1943). Whooping Cough. Springfield, Ill., U.S.A.: Chas. C. Thomas.

Leslie, P. H. \& Gardner, A. D. (1931). The phases of H. pertussis. J. Hyg., Camb., 31, 423.

Miles, A. A. \& Misra, S. S. (1938). The estimation of the bactericidal power of the blood. J. Hyg., Camb., 38, 732.

Norton, J. F. \& Dingle, J. H. (1935). Virulence tests for typhoid bacilli and antibody relationships in antityphoid sera. Amer. J. publ. Hlth, 37, 803.

Proom, H. (1947). The immunological aspects of experimental Haemophilus pertussis infection. J. Path. Bact. 59, 165.

Reed, L. J. \& Muench, H. (1938). A simple method of estimating fifty per cent endpoints. Amer. J. Hyg. 27, 493.

Strean, L. P. (1943). Attempts to enhance the virulence of $H$. pertussis by serial passage in mice. Amer. J. Dis. Child. 65, 895.

Toomey, J. A., Ranta, K. \& Takacs, W. S. (1935). The virulence of $H$. pertussis. J. infect. Dis. 57, 286.

(Received 18 May 1950)

\title{
NOTE ON THE RELATION BETWEEN LD50 AND AVERAGE TIME TO DEATH IN 25 STRAINS OF H. PERTUSSIS
}

\author{
By J. O. IRWIN \\ Medical Research Council Statistical Research Unit, London School of \\ Hygiene and Tropical Medicine, London
}

The values of the LD50 at weekly intervals for 8 weeks are shown in Table 5 (p. 254). Clearly these values vary with the time at which they were calculated. A ratio of 3 to 1 is about significant, judging from Kendrick's tests (1948), and the Table shows greater variations than this at different times. Nevertheless, whenever the LD 50's are calculated they agree very well in the order in which they place the different strains. The coefficient of concordance, which would be unity for perfect agreement in order, is actually 0.85. Accordingly, the strains were classified into five groups of virulence as judged by the LD 50 at 56 days, as follows: less than 1 million; 1 million and less than 5 million; 5 million and less than 25 million; 25 million and less than 125 million; more than 125 million.

Two questions needed answering: (a) Does the relative rapidity of killing at different doses differ significantly in different strains? $(b)$ If so, are these variations from strain to strain correlated significantly with virulence as judged by the LD 50? The answer to $(a)$ was $Y e s$, and to $(b)$ No. The values of average 